\title{
Pembelajaran e-learning berbasis Chamilo pada pembelajaran simulasi dan komunikasi digital
}

\author{
Izzah Tiari *, Zulkardi Zulkardi, Sardianto Markos Siahaan \\ Educational Technology Masters Study Program, Universitas Sriwijaya. \\ Jalan Masjid Al Ghazali, Bukit Lama, Palembang, Sumatera Selatan 30128, Indonesia. \\ izzah.tiari@live.com \\ * Corresponding Author
}

\section{ARTICLE INFO}

\section{Article History}

Received:

2 December 2019;

Revised:

16 December 2019;

Accepted:

16 January 2020

\section{Keywords}

Chamilo;

E-learning;

Pembelajaran

kolaboratif;

Collaborative learning

\begin{abstract}
E-learning berbasis Chamilo telah berhasil dikembangkan pada pembelajaran simulasi dan komunikasi digital di SMK Negeri 5 Palembang. Penelitian bertujuan untuk mengetahui kevalidan, kepraktisan, dan efektifitas e-learning terhadap mata pelajaran fitur kolaboratif daring. Tahapan Penelitian pengembangan ini terdiri dari tahap perencanaan, desain, dan pengembangan. $E$ learning yang telah dikembangkan kemudian diuji kevalidan oleh ahli, diuji kepraktisan oleh peserta didik, dan diuji efektifitas dengan mengimplementasikan e-learning di SMK Negeri 5 Palembang. Pengembangan e-learning menggunakan model Alessi dan Trollip. Dari penelitian ini didapatkan bahwa 1.) E-learning teruji kevalidan dengan penilaian oleh ahli media terhadap $e$ learning sebesar 89,47\%, penilaian oleh ahli materi sebesar $84,62 \%$, dan penilaian ahli desain pembelajaran sebesar $81,82 \%$; 2.) E-learning teruji kepraktisannya dengan penilaian dari 3 peserta didik tingkat rendah, sedang, dan atas dengan rata-rata sebesar $86,10 \%$; dan 3.) E-learning teruji efektifitas meningkatkan hasil belajar peserta didik dilihat dari adanya gain sebesar 0,70 yang termasuk kedalam kategori tinggi.
\end{abstract}

E-Learning of Chamilo based has been developed for materials simulation and communication digital in SMK Negeri 5 Palembang. The research aims to know validity, practicality, and effectiveness e-learning features on the subject matter of online collaboration features. This research development stage consists of the plan, design, and development phase. E-learning features that have been developed and then tested validity by experts, tested practicality by students, and tested for effectiveness by implementation elearning in SMK Negeri 5 Palembang. The development of e-learning used the Alessi and Trollip model. From this study, it was found that 1.) The assessment e-learning features have been validity tested by media experts at $89.47 \%$, by subject matter experts of $84,62 \%$, and by learning design experts of $81,82 \%$; 2.) The assessment of e-learning features has been practicality tested by three students' low level, medium, and high an average by $86,10 \%$; and 3.) E-learning features have been effectively tested to improving students learning outcomes seen from a gain of 0.70 included in the high category.

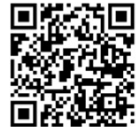

This is an open access article under the CC-BY-SA license.

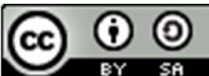




\section{PENDAHULUAN}

Perkembangan teknologi komunikasi dan informasi serta pendidikan dapat dikolaboratifkan dalam satu teknologi pendidikan masa kini yang disebut dengan e-learning. Perkembangan TIK menjadi acuan untuk mengembangkan pembelajaran TIK di Sekolah Menengah Kejuruan (SMK) yang salah satunya terletak pada mata pelajaran Simulasi dan Komunikasi Digital (Siskomdig) yang dijelaskan pada Undang-Undang Nomor 20 Tahun 2003 Pasal 15 memiliki tujuan menjadikan dan mempersiapkan lulusan yang produktif, mampu bekerja secara mandiri, ulet, gigih dalam berkompetensi, beradaptasi, dan sikap profesional di lingkungan kerja. Pembelajaran Siskomdig diharapkan dapat membekali peserta didik dalam perkembangan TIK di era sekarang ini dan masa yang akan datang. Proyek Chamilo didirikan pada awal tahun 2010 sebagai hasil dari percabangan dari platform e-learning perangkat lunak bebas lainnya, yang dimaksudkan untuk melindungi keterbukaan mendasar dan karakter bebas Learning Management System (LMS) ini. Chamilo secara tidak langsung mewarisi proyek Claroline yang pertama kali diterbitkan pada tahun 2001. Misi dari Asosiasi Chamilo adalah untuk meningkatkan pendidikan di seluruh dunia dan untuk memastikan pengembangan perangkat lunak Chamilo sebagai produk sumber terbuka yang membantu mengurangi kesenjangan digital antara negara kaya dan miskin.

Peserta didik menjadi salah satu faktor meningkatnya statistik penggunaan internet. Proses pembelajaran dengan memanfaatkan TIK berbasis internet dapat mewujudkan suasana belajar dan proses pembelajaran agar peserta didik aktif mengembangkan potensi dirinya untuk memiliki kekuatan spiritual keagamaan, pengendalian diri, kepribadian, kecerdasan, akhlak mulia, serta keterampilan yang diperlukan dirinya, masyarakat, bangsa dan negara. Pembelajaran TIK berbasis internet salah satunya terdapat pada materi fitur perangkat lunak pembelajaran kolaboratif daring. Karakteristik peserta didik terhadap TIK berdasarkan studi pendahuluan sebagai berikut: 1.) Peserta didik pada tingkat bawah dan tengah pada umunya memiliki motivasi belajar yang rendah, namun peserta didik tingkat atas memiliki motivasi belajar sedang; 2.) Peserta didik tingkat bawah pada umumnya memiliki pengetahuan kognitif yang rendah, dan peserta didik tingkat sedang dan tinggi memiliki pengetahuan kognitif yang sedang; 3.) Hanya peserta didik tingkat tinggi yang memiliki fasilitas komputer di rumah; 4.) Peserta didik terbiasa dengan tampila website; 5.) Peserta didik memiliki kemampuan mengetik dengan rata-rata nilai 7 dari 10 ; 6.) Peserta didik memiliki kemampuan menggunakan komputer dengan rata-rata nilai 8 dari 10; 7.) Peserta didik memiliki kemampuan mengakses web dengan rata-rata nilai 7 dari 10; dan 8.) Peserta didik rata-rata memiliki kesediaan waktu 1 hingga 1,5 jam dalam mengakses internet untuk belajar.

Berdasarkan karakteristik peserta didik tersebut, dilakukan analisis kebutuhan terhadap peserta didik dalam pembelajaran Siskomdig bahwa peserta didik merasa jenuh dan minim rasa ingin tahu terhadap materi fitur kolaboratif daring yang disampaikan berupa teks dan gambar berdasarkan buku, menampilkan teori pada proyektor, ceramah dan diskusi. Peserta didik lebih menyukai pembelajaran langsung (praktik) dan mengharapkan dapat melakukan pembelajaran yang menyenangkan seperti pada sosial media, yang dapat membuat status, mengirim pesan pada teman, berkomentar, menghubungi teman dengan videocall atau video conference, dan materi pembelajaran berupa gambar dan video seperti yang terdapat pada Chamilo. Pembelajaran Siskomdig mempunyai tujuan agar peserta didik dapat melaksanakan tugas, memiliki kinerja, keterampilan, menalar, mengolah, menyaji, mempersepsi, kesiapan, meniru, membiasakan, dan mahir memanfaatkan TIK sesuai dengan kompetensi yang telah ditentukan. Pembelajaran virtual class belum menggunakan fitur real time learning, sehingga pendidik tidak bisa memantau kehadiran peserta didik dalam kelas maya secara jarak jauh. Pendidik merasa perlu menggunakan aplikasi pembelajaran yang dilengkapi fitur video conference. Selain itu, permasalahan terlihat dari hasil belajar 36 peserta didik rata-ratanya hanya 70 (nilai pengetahuan) dan 61 (nilai keterampilan) yang belum mencapai Kriteria Kelulusan Minimal (KKM) yaitu 71.

Laboratorium Komputer di SMK Negeri 5 Palembang memiliki fasilitas yang sangat mendukung untuk pembelajaran simulasi dan komunikasi digital. Fasilitas tersebut dibuktikan dengan tersedia komputer yang cukup dan sudah terhubung dengan jaringan internet yang memungkinkan guru dapat melaksanakan pembelajaran dengan memanfaatkan sarana dan prasarana sekolah lebih maksimal. Komunikasi dan kolaboratif antar kelas dengan munculnya beragam kebutuhan dan 
inovasi manusia yang dapat disebut dengan periode era informasi. Metode e-learning dibandingkan dengan metode pengajaran tradisional menunjukkan berbagai manfaat bahwa metode e-learning dapat cenderung meningkatan pesat. Selain itu, psikolog-psikolog pendidikan percaya bahwa pembelajaran harus diatur dengan cara masing-masing peserta didik berdasarkan kemampuan mereka yang terlibat dalam pembelajaran kegiatan (Somayeh et al., 2016, p. 87).

Penelitian e-learning yang dilakukan Wu, Chen, dan Chen (2017, p. 903) menghasilkan perbedaan yang signifikan antara kelas eksperimen dan kelas kontrol. Sistem e-learning dianggap adaptif ketika mereka dapat berubah secara dinamis sebagai respons terhadap perbedaan masing-masing peserta didik. Penelitian ini teruji efektif dengan mengembangkan sistem e-learning berdasarkan kerangka teoritis terintegrasi yang terdiri dari strategi pembelajaran adaptif, teori perancah dinamis, dan mekanisme penilaian diri. Sistem e-learning adaptif yang dikembangkan dapat meningkatkan kemampuan peserta didik yang dinamis dan menyampaikan materi pembelajaran yang sesuai untuk semua peserta didik. Berdasarkan uraian tersebut, sesuai dengan permasalahan dan kebutuhan peserta didik, maka perlu dilakukan pengembangan e-learning berbasis Chamilo pada pembelajaran simulasi dan komunikasi digital untuk mengetahui kevalidan, kepraktisan, dan keefektifan e-learning dilihat dari hasil belajar.

\section{METODE}

Penelitian ini merupakan penelitian yang bertujuan untuk mengetahui kevalidan, kepraktisan, dan efektifitas penggunaan terhadap pengembangan e-learning untuk pembelajaran kolaboratif daring dan kelas maya. Penelitian yang digunakan adalah penelitian kuantitatif dengan metode research and development. Tiga kriteria untuk mengukur kualitas suatu produk yaitu validitas, kepraktisan dan efektifitas. Tahapan penelitian pengembangan media meliputi tahap perencanaan, desain, dan pengembangan (Alessi \& Trollip, 2001, p. 408). Penelitian ini akan dilaksanakan pada semester ganjil tahun ajaran 2019/2020 di Laboratorium Komputer kelas X Multimedia sebanyak 30 peserta didik di SMK Negeri 5 Palembang.

Metode Alessi dan Trollip (2001, p. 408) dalam penelitian ini digunakan sebagai development research. Pada tahapan prototip terdiri dari tahap perencanaan, tahap desain dan tahap pengembangan. Tahap perencanaan meliputi: analisis kebutuhan, analisis kurikulum, analisis sarana prasarana, analisis karakteristik peserta didik, dan analisis hasil belajar dan media. Tahap desain meliputi pembuatan konsep pembelajaran, flowchart, storyboard, kode program, dan persiapan prototip e-learning. Sedangkan, tahap pengembangan terdiri dari pengembangan konter e-learning, melakukan uji alpha dan revisi, uji beta dan revisi, lalu dilanjutkan dengan uji lapangan untuk mendapatkan hasil belajar peserta didik.

Teknik pengumpulan data yang dilakukan, yaitu: wawancara, observasi, angket atau instrumen, dan tes hasil belajar peserta didik. Pada penelitian ini wawancara guru dilakukan pada studi pendahuluan untuk menganalisis kebutuhan dan karakteristik peserta didik, tujuannya guna mengetahui kebutuhan terhadap pemilihan materi yang akan dikembangkan dalam produk e-learning. Pada tahap ini wawancara dilakukan dengan guru dan peserta didik. Kisi-kisi wawancara terhadap guru terdiri dari aspek pembelajaran dan aspek materi. Aspek pembelajaran terdiri dari pokok item yakni hambatan, silabus, RPP, media, dan sarana prasarana, sedangkan aspek materi dengan pokok item isi materi.

Tujuan observasi adalah untuk mengetahui kesulitan yang dihadapi oleh peserta didik dan mengetahui kemampuan peserta didik dalam menggunakan komputer secara langsung. Teknik observasi yang digunakan pada kegiatan studi pendahuluan adalah dengan mengamati situasi dan kondisi pembelajaran yang ada dilaksanakan di SMK Negeri 5 Palembang dan pada saat uji lapangan untuk mengetahui aktivitas pembelajaran. Observasi kemampuan terdiri dari delapan aspek diantaranya: 1.) Motivasi belajar; 2.) Pengetahuan kognitif; 3.) Fasilitas komputer; 4.) Terbiasa dengan web; 5.) Kemampuan mengetik; 6.) Akses komputer; 7.) Akses web; dan 8.) Ketersediaan waktu.

Pada penelitian ini angket dilakukan pada tahap uji alpha (validasi), dan uji beta (praktisasi). Penelitian ini menggunakan angket yang merujuk pada Alessi dan Trollip (2001) jenis checklist yang dianalisis dengan menggunakan pilihan "dapat diterima" atau "perlu tindak lanjut". Instrumen validasi desain pembelajaran terdiri dari 11 aspek antara lain: 1.) Tujuan pembelajaran; 2.) Kapasitas 
kognitif; 3.) Pendekatan pembelajaran; 4.) Strategi pembelajaran; 5) Model pembelajaran; 6.) Interaktivitas; 7.) Penyajian materi; 8.) Pertanyaan/soal; 9.) Menjawab pertanyaan; 10.) Kualitas umpan balik; dan 11.) Tingkat penguasaan. Selanjutnya peneliti merancang instrumen validasi ahli media yang terdiri dari 19 antara lain: menampilkan, mode presentasi, kualitas teks, gambar, audio, video, masukan, jarak, alat bantu navigasi, konsistensi, memulai Kembali, bookmark pasif, bookmark aktif, catatan dan data, keamanan dan aksebilitas, banyak data, tindakan pengguna normal, tindakan pengguna tidak biasa, dan komputer, perangkat lunak, dan browser. Sedangkan, Instrument validasi materi terdiri dari 13 aspek antara lain: sesuai tujuan, struktur konten, bahasa, gaya, serta tata bahasa, tingkat keterbacaan, bias budaya dalam bahasa, bias budaya dalam referensi, istilah teknis dan jargon, pengejaan, tata bahasa, dan tanda baca, glosarium, kata penting, kata pengantar, arahan, dan kata bantuan. Hasil angket dari peserta didik akan dijadikan acuan untuk melakukan perbaikan terhadap media yang dikembangkan. Instrumen praktisasi peserta didik yang terdiri 12 aspek antara lain: menampilkan, mode presentasi, kualitas teks, gambar, audio, video, masukkan, spasi, bahasa, gaya, dan tata bahasa, pengantar, arah, dan kata bantuan.

Tes pada penelitian ini digunakan untuk mengumpulkan data hasil belajar peserta didik setelah menggunakan multimedia interaktif. Tes mengukur efektifitas e-learning yang dikembangkan terhadap hasil pembelajaran peserta didik melalui pengumpulan data hasil tes peserta didik. Tes dilaksanakan dua kali yaitu tes awal (pretest) dan tes akhir (posttest) dan tes kompetensi dalam menggunakan Fitur Electronic Learning berbasis Chamilo.

Teknik analisis data pada penelitian ini menggunakan wawancara dan observasi, angket/instrumen, dan tes hasil belajar peserta didik. Analisis data wawancara dan observasi dilakukan dengan cara kualitatif, menurut Sugiyono (2016, p. 13) penelitian kuantitatif merupakan metode penelitian yang berlandaskan pada filsafat positivisme, digunakan untuk meneliti pada populasi atau sampel tertentu, teknik pengambilan sampel pada umumnya dilakukan secara random, pengumpulan data menggunakan instrumen penelitian, analisis data bersifat kuantitatif. Berdasarkan data yang diperoleh pada penelitian akan dideskripsikan dalam bentuk paragraf. Instrumen validasi ahli dan instrumen praktisasi pada penelitian ini memiliki dua pilihan jawaban yaitu "diterima" dan "perlu tindak lanjut". Analisis pada instrumen validasi ahli dan praktisasi dilakukan dengan menghitung jumlah "diterima" dibandingkan dengan jumlah "perlu tindak lanjut". Data penelitian yang bersifat kualitatif seperti komentar dan saran dijadikan dasar dalam melakukan revisi terhadap produk $e$ learning berbasis Chamilo yang dikembangkan.

Analisis data tes hasil belajar peserta didik memiliki rentang 1-100. Hasil belajar peserta didik diukur dari nilai pengetahuan dan keterampilan untuk mengetahui peningkatan hasil belajar peserta didik guna melihat keefektifan pembelajaran e-learning menggunakan Chamilo dalam pembelajaran. Pada tahap ini hasil belajar peserta didik berupa pretest sebelum pembelajaran menggunakan Chamilo dan posttest setelah pembelajaran menggunakan Chamilo. Data yang diperoleh dari hasil pretest dan posttest dihitung menggunakan rumus yang dapat dilihat pada Rumus 1 .

$$
\text { Nilai }=\frac{\text { Skor yang diperoleh }}{\text { Skor Maksimal }} \times 100
$$

Berdasarkan perhitungan dilihat dari masing-masing nilai pretest dan posttest peserta tersebut, selanjutnya digunakan gain yang dinormalisasi $N$-gain Hake (2002, p. 2). Gain Hake menurut Fadaei (2019, p. 31) dapat digunakan untuk mengukur efektifitas yang relatif dari berbagai teknik pengajaran begitupun untuk pembelajaran e-learning. $N$-gain dapat dihitung dengan persamaan yang dapat dilihat pada Rumus 2.

$$
N-\text { gain }=\frac{\bar{x} \text { posttest }-\bar{x} \text { pretest }}{100-\bar{x} \text { pretest }}
$$

Keterangan

$\bar{x}$ pretest $\quad:$ rata-rata tes awal

xposttest : rata-rata tes akhir 
Langkah-langkah analisis data hasil tes belajar terhadap e-learning berbasis Chamilo antara lain: 1.) Mendapatkan rata-rata nilai pretest dan posttest; 2.) Menghitung gain berdasarkan nilai pretest dan posttest; dan 3.) Mengelompokkan kriteria tingkat hasil $\mathrm{N}$-gain sesuai pendapat Fadeai (2019, p. 37) dengan data yang dapat dilihat pada Tabel 1.

Tabel 1. Kategori Perolehan N-Gain Score

\begin{tabular}{cc}
\hline Kriteria Nilai $N$-gain & Kategori \\
\hline Jika $N$-gain $\geq 0,7$ & Tinggi \\
Jika $0,7>N$-gain $\geq 0,3$ & Sedang \\
Jika $N$-gain $<0,3$ & Rendah \\
\hline
\end{tabular}

Berdasarkan nilai pengetahuan dan keterampilan, lalu dilakukan analisis nilai rata-rata hasil belajar. Nilai rata-rata hasil belajar dihitung dengan Rumus 3.

$$
\text { Mean }=(60 \% \mathrm{x} \text { Teori })+(40 \% \mathrm{x} \text { Praktik })
$$

Keterangan:

Teori = Nilai tes pengetahuan

Praktik $=$ Nilai tes keterampilan

Kategori hasil belajar peserta didik setelah menggunakan e-learning berbasis Chamilo dapat dilihat pada Tabel 2. Perbedaan hasil yang didapat peserta didik pada pretest dan posttest dapat dilihat dengan menggunakan penilaian Kriteria Ketuntasan Minimal (KKM) mata pelajaran simulasi dan komunikasi digital (siskomdig) yaitu pada rentang nilai 71-100 dengan keterangan tuntas KKM dan rentang 0-71 dengan keterangan tidak tuntas KKM.

Tabel 2. Kategori Hasil Belajar

\begin{tabular}{ccc}
\hline Nilai & Predikat & Dengan Huruf \\
\hline $86-100$ & Sangat Baik & A \\
$71-85$ & Baik & B \\
$56-70$ & Cukup & C \\
$40-55$ & Buruk & D \\
$0-39$ & Sangat Buruk & E \\
\hline
\end{tabular}

\section{HASIL DAN PEMBAHASAN}

Pada bagian ini, peneliti menguraikan hasil dan pembahasan yang telah dilakukan mengenai pengembangan fitur electronic learning berbasis Chamilo pada pembelajaran simulasi dan komunikasi digital di Sekolah Menengah Kejuruan. Penelitian ini diharapkan menghasilkan media yang valid, praktis dan efektif dengan menggunakan multimedia interaktif.

Hasil

\section{Tahap Perencanaan}

Berdasarkan analisis kebutuhan yang dilakukan dengan wawancara terhadap pendidik atau fasilitator, terdapat beberapa temuan antara lain: 1.) Materi yang disampaikan berupa teks dan gambar (disampaikan berdasarkan buku). Penyampaiaan materi dengan teks dan gambar saja membuat peserta didik jenuh dan minim rasa ingin tahu terhadap materi fitur kolaboratif daring; 2.) Metode pembelajaran yang diterapkan secara umum dilakukan dengan menampilkan teori pada proyektor, ceramah dan diskusi. Dengan menerapkan proses pembelajaran tersebut, peserta didik mengalami kesulitan untuk memahami materi fitur kolaboratif daring; 3.) Proses pembelajaran fitur kolaboratif daring menggunakan e-learning, namun belum sepenuhnya digunakan pada proses pembelajaran 
fitur kolaboratif daring, sehingga rendahnya hasil belajar keterampilan peserta didik; 4.) Pada $e$ learning yang digunakan sebelumnya dirasakan kurang real time untuk pembelajaran simulasi dan komunikasi daring, sehingga guru tidak dapat memantau secara langsung kegiatan peserta didik dan kehadiran peserta didik pada e-learning tersebut; 5.) Pada media yang digunakan sebelumnya, dirasakan belum sepenuhnya memenuhi kriteria fitur kolaboratif daring yang diharapkan sebagai tujuan pembelajaran. Fitur tersebut seperti video conference dan real time learning; 5.) Hal tersebut memungkinkan kurangnya pemahaman peserta didik terhadap fitur kolaboratif daring, sehingga hasil belajar peserta kurang baik, yaitu dengan nilai pengetahuan rata-rata hanya 70 (nilai pengetahuan) dan 61 (nilai keterampilan); 6.) Diperlukan e-learning berbasis Chamilo yang dapat membuat peserta didik mengikuti pembelajaran sehingga pemahaman dan hasil belajar peserta didik meningkat.

Berdasarkan hasil analisis karakteristik peserta didik bahwa peserta didik memiliki kemampuan untuk mengakses website yang akan dikembangkan, memiliki kemampuan mengakses komputer yang relatif tinggi dengan nilai 7 dari 10, dan memiliki ketersediaan waktu dalam mengakses website lebih dari 1 jam. Pengembangan e-learning berbasis Chamilo dapat digunakan peserta didik dengan karakteristik tersebut karena e-learning dapat digunakan di laboratorium maupun di luar laboratorium siskomdig (dimana saja).

\section{Tahap Desain}

Pada tahap desain, peneliti membuat desain e-learning berbasis Chamilo. Tahap desain terdiri dari membuat konsep pembelajaran, membuat flowchart, membuat storyboard, membuat kode program, dan menyiapkan prototip. Materi pokok yang akan dikembangkan pada e-learning terdiri dari 4 jenis materi diantaranya: 1.) Factual yang terdiri dari materi pokok pembelajaran kolaboratif daring (kelas maya) dan prosedur pendaftaran social learning network; 2.) Konseptual yang terdiri dari macam-macam pembelajaran daring (kelas maya) dan fitur-fitur Chamilo dalam kegiatan pembelajaran; 3.) Prosedural dengan materi pokok yaitu langkah-langkah mengaplikasikan pembelajaran daring menggunakan aplikasi Chamilo; dan 4) Metakognitif dengan materi pokok penggunaan fitur-fitur Chamilo untuk berkomunikasi, belajar, dan mengirim tugas.

Desain flowchart atau diagram alir digunakan untuk memperlihatkan urutan dan hubungan antar proses beserta instruksinya sesuai dengan desain konsep pembelajaran. Urutan serta hubungan antar proses instruksi ini digambarkan dengan simbol-simbol tertentu dan saling terhubung menggunakan garis penghubung. Flowchart didesain menggunakan aplikasi DIA Diagram. Setelah membuat flowchart, peneliti membuat storyboard. Storyboard merupakan gambaran rancangan dari sebuah e-learning yang akan dikembangkan. Storyboard didesain menggunakan aplikasi CorelDraw X7 dengan pengaturan kertas berukuran A4. Tahap selanjutnya yaitu membuat kode program dan menyiapkan prototip Chamilo versi 1.11.8 yang akan dikembangkan.

\section{Tahap Pengembangan}

Hasil tahap pengembangan pada penelitian ini dilakukan oleh peneliti dengan hasil sebuah multimedia interaktif yang teruji valid, praktis, dan efektif meningkatkan hasil belajar peserta didik. Pengembangan dilakukan dengan menggunakan komputer yang ada di Laboratorium Siskomdig SMK Negeri 5 Palembang.

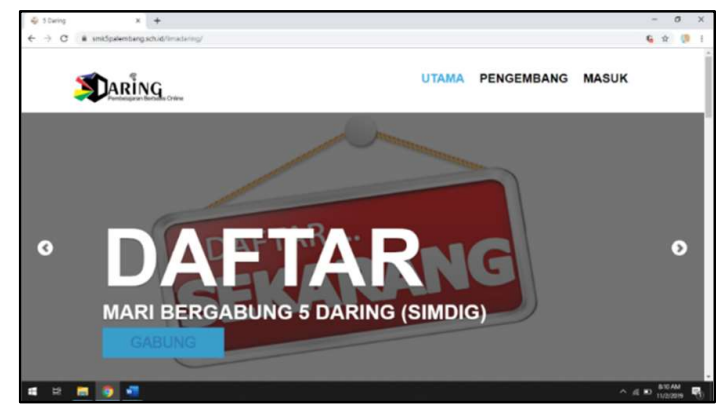

Gambar 1. Tampilan Halaman Utama E-Learning yang Dikembangkan 


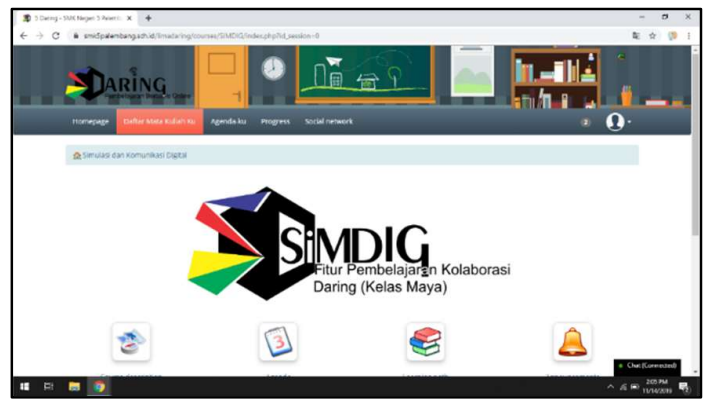

Gambar 2. Tampilan Halaman Course

Tahap pengembangan dibagi menjadi beberapa tahapan, diantaranya mengembangkan $e$ learning, melakukan uji validasi ahli lalu revisi, dan melakukan uji praktisasi terhadap peserta didik. Setelah menyelesaikan pembuatan e-learning berbasis Chamilo, seperti pada laman website www.smk5palembang.sch.id/limadaring. Langkah selanjutnya yang dilakukan oleh peneliti adalah meminta penilaian dan saran serta masukan dari ahli dalam hal ini memvalidasi produk yang sedang dikembangkan. Tahap ini merupakan tahap yang penting karena media yang dihasilkan akan dilakukan penilaian oleh ahli untuk mengetahui produk media sudah memiliki kategori valid dan memiliki kelayakan untuk di uji cobakan pada proses pembelajaran. Uji ini melakukan penilaian terhadap aspek materi, aspek pedagogik dan aspek tampilan.

\section{Uji Alpha dan Revisi}

Validasi terhadap ahli materi konten bahasa teruji valid 11 item pernyataan dari total 13 item pernyataan. Validasi ahli materi bidang bahasa menyatakan bahwa materi terhadap konten bahasa sudah valid $(84,62 \%)$ dengan revisi perbaikan Teknik penulisan, tata bahasa dan penulisan kata pada isi konten. Validasi terhadap ahli desain pembelajaran teruji valid 9 item pernyataan dari total 11 item pernyataan. Validasi ahli desain pembelajaran menyatakan bahwa desain pembelajaran sudah valid $(81,82 \%)$ dengan revisi penambahan indikator ranah $\mathrm{C} 4$ dan umpan balik berupa sertifikat sesuai bidang yaitu bidang komputer. Validasi terhadap ahli media teruji valid 17 item pernyataan dari total 19 item pernyataan. Validasi ahli media menyatakan bahwa e-learning sudah valid $(89,47 \%)$ dengan revisi penambahan audio dan video pada e-learning agar materi dapat disampaikan secara pendengaran dan dibuat tutorial berupa video tidak hanya teks.

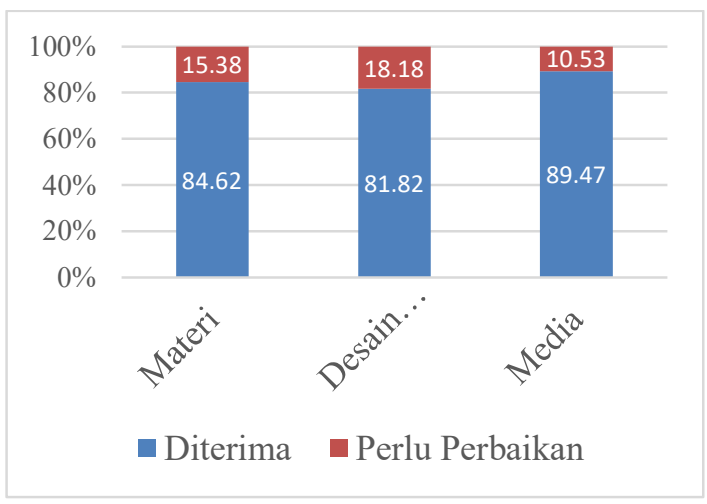

Gambar 3. Validasi Uji Alpha oleh Ahli

\section{Uji Beta dan Revisi}

Setelah melakukan uji validasi, maka multimedia yang dikembangkan dilanjutkan uji beta/ kepraktisan multimedia. Uji beta/kepraktisan melibatkan 3 peserta didik kelas XI kompetensi keahlian Multimedia SMK Negeri 5 Palembang yang memiliki kriteria berpotensi dalam 
pembelajaran, kemampuan rata-rata, dan salah seorang memiliki kemampuan yang rendah dalam melakukan pembelajaran. Pelaksanaan uji coba berdurasi 6 jam pelajaran yaitu sebanyak 2 pertemuan. Tujuan uji beta ini adalah untuk mengetahui kepraktisan produk yang dikembangkan dapat mudah digunakan oleh peserta didik. Uji coba dilakukan di Laboratorium Komputer Multimedia SMK Negeri 5 Palembang.

Uji kepraktisan dilakukan dengan menggunakan instrumen praktisasi yang telah disiapkan. Intrumen praktisasi meliputi 14 item pernyataan yaitu menampilkan, mode presentasi, kualitas teks, gambar, audio, video, memasukkan, spasi, gaya bahasa, tata bahasa, pengantar, arah, dan help. Rekapitulasi uji beta dapat dilihat pada Tabel 3.

Tabel 3. Rekapitulasi Uji Beta E-learning berbasis Chamilo

\begin{tabular}{cccc}
\hline Peserta didik & Nilai Maks & Hasil & Persentase \\
\hline PD 1 & 14 & 12 & $85,71 \%$ \\
PD 2 & 14 & 13 & $92,85 \%$ \\
PD 3 & 14 & 12 & $85,71 \%$ \\
Total & 42 & 37 & $88,09 \%$ \\
\hline
\end{tabular}

Berdasarkan hasil uji praktisasi ketiga peserta didik, e-learning berbasis Chamilo teruji secara praktis $(88,10 \%)$ dengan memenuhi 37 item pernyataan dari total ketinyanya 42 item pernyataan. Penemuan dari hasil uji beta dituliskan dalam bentuk saran oleh ketiganya untuk memperlambat video tutorial pada materi dan dua diantaranya memberi saran untuk memperlambat audio. Selanjutnya, peneliti memperbaiki e-learning sesuai dengan saran yang telah diberikan.

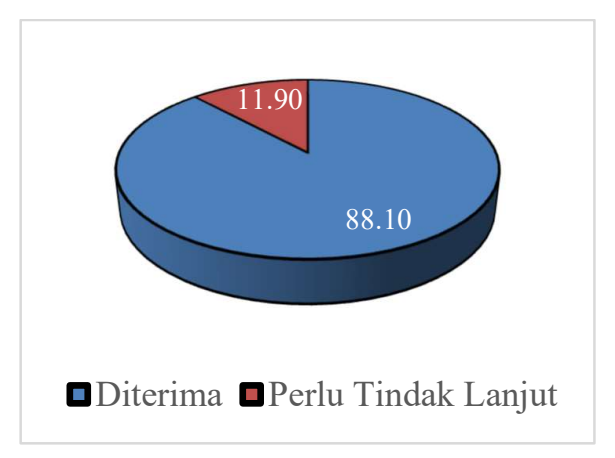

Gambar 4. Hasil Kepraktisan E-learning berbasis Chamilo

\section{Uji Lapangan/Hasil}

Tahap Uji Lapangan dilaksanakan di Laboratorium Siskomdig dengan melibatkan 30 peserta didik kelas X kompetensi multimedia SMK Negeri 5 Palembang. Hasil tahap uji lapangan berupa analisis nilai pretest, posttest, dan ketuntasan hasil balejar e-learning berbasis Chamilo. Hasil uji lapangan menunjukan peningkatan nilai peserta didik pada kegiatan pretest sebelum menggunakan e-learning berbasis Chamilo dan posttest setelah menggunakan e-learning berbasis Chamilo. Penilaian keefektifan diukur dengan menggunakan $\mathrm{N}$-gain, sehingga didapatkan dari nilai rata-rata perolehan nilai pretest dan posttest adalah 0.70 dengan kriteria tinggi. Hal ini menunjukan penggunaan e-learning berbasis Chamilo mempunyai dampak efektivitas yang baik terhadap hasil belajar peserta didik. Peningkatan nilai peserta didik dari pretest ke posttest menunjukan bahwa menggunakan e-learning berbasis Chamilo dapat membantu peserta didik dalam meningkatkan motivasi, sehingga pengetahuan dan keterampilan peserta didik meningkat.

Peningkatan yang signifikan antara nilai pretest ke posttest yang dialami peserta didik berbeda sesuai dengan interaksi peserta didik terhadap multimedia. Namun secara keseluruhan pengaruh e-learning berbasis Chamilo yang dikembangkan dapat membantu peserta didik dalam pemahaman konsep materi yang diberikan melalui multimedia ini. Berdasarkan angket respon yang 
diberikan kepada peserta didik terhadap penggunaan fitur e-learning berbasis Chamilo sangat mendapat respon positif dari peserta didik karena dapat diolah sesuai dengan keinginan mereka, materi mudah dipahami, dan terdapat video untuk memudahkan peserta didik dalam pemahaman dan keterampilan. Namun, terdapat beberapa kekurangan seperti koneksi internet yang terkadang menjadi kendala dalam mengakses website.

Pembahasan

Penelitian pengembangan fitur e-learning berbasis Chamilo pada pembelajaran simulasi dan komunikasi daring di SMK Negeri 5 Palembang telah melewati semua tahapan prosedur. E-learning ini diharapkan mampu memberikan pengetahuan dan suasana baru bagi peserta didik yang selama ini memiliki keterbatasan dalam mengikuti pembelajaran. multimedia interaktif ini juga diharapkan memaksimalkan proses pembelajaran dengan memanfaatkan teknologi. Penelitian yang telah dilaksanakan ini merupakan jenis penelitian pengembangan produk yang bertujuan untuk menghasilan produk pembelajaran yang memiliki nilai valid yang berdampak pada nilai praktis dan efektif dalam meningkatkan hasil belajar pendidik. Pengembangan ini menggunakan model pengembangan Alessi dan Trollip (2001, p. 408) yang terdiri dari tahapan meliputi tahap perencanaan, tahap desain, dan tahap pengembangan.

Model pengembangan Alessi dan Trollip (2001, p. 408) pada tahap perencanaan (planning), peneliti melakukan analisis kebutuhan, mengidentifikasi karakteristik peserta didik, mengidentifikasi kurikulum, mengidentifikasi sarana dan prasarana, mengidentifikasi media, dan mengidentifikasi hasil belajar. Pada tahap desain (design), peneliti mulai mengembangkan konsep pembelajaran, membuat flowchart dan storyboard, mengembangkan kode program website, dan mempersiapkan prototype Chamilo versi 1.11.8. Selanjutnya, pada tahap pengembangan (development), peneliti menyiapkan materi pendukung, membuat gambar yang relevan, membuat video dan audio, mengabungkan semua media dalam satu prototype Chamilo, melakukan uji alpha (validasi ahli) untuk mengetahui kevalidan dari media yang dikembangkan, melakukan revisi produk, melakukan uji beta untuk melihat kepraktisan media, melakukan revisi produk, dan melakukan uji coba untuk mengetahui efektivitas terhadap hasil belajar peserta didik.

Penelitian ini berhasil mengembangkan fitur e-learning yang telah teruji valid, berdasarkan hasil uji validasi oleh validator menunjukan bahwa multimedia ini memenuhi syarat dari aspek materi, media, dan desain pembelajaran. Validasi materi dilakukan sebanyak satu kali oleh guru mata pelajaran simulasi dan komunikasi digital di SMK negeri 5 Palembang. Validasi materi yang telah diujikan kepada validator ahli materi menyatakan bahwa materi layak $(84,61 \%)$ digunakan dalam $e$ learning dengan revisi perbaikan teknik penulisan, tata bahasa dan penulisan kata. Validator ahli materi juga memberikan saran untuk menambahkan gambar pada menu materi dan memindahkan materi pendaftaran di halaman depan. Validasi kedua diujikan pada aspek desain pembelajaran yang divalidasi oleh ahli validasi sebanyak satu kali. Validasi desain pembelajaran yang telah diujikan kepada validator ahli desain menyatakan bahwa desain pembelajaran layak $(81,82 \%)$ diimplementasikan dalam kegiatan pembelajaran fitur e-learning dengan revisi penambahan indikator ranah $\mathrm{C} 4$ pada tujuan pembelajaran dan pertanyaan/soal serta menambahkan umpan balik berupa sertifikat yang didapatkan setelah melaksanakan pembelajaran. Validasi ketiga diujikan oleh validator ahli media sebanyak satu kali yang dinyatakan layak $(89,47 \%)$ diimplementasikan pada pembelajaran fitur $e$-learning dengan revisi penambahan konten mudia berupa video dan audio.

Kepraktisan e-learning dilakukan pada tahap uji beta yang dilakukan oleh tiga orang peserta didik dengan kemampuan rendah, sedang, dan tinggi. E-learning dinyatakan layak $(88,09 \%)$ disebabkan e-learning dikembangkan telah memenuhi kebutuhan peserta didik karena materi yang ditampilkan mudah dipahami dan peserta didik dapat praktik langsung sesuai dengan materi yang telah disampaikan. Peserta didik juga menyatakan bahwa e-learning yang digunakan sudah baik dengan adanya gambar dan video, namun perlu memperlambat penampilan video, penambahan backsound, dan memperjelas audio agar e-learning menjadi lebih praktis dan menarik.

Uji lapangan/ hasil belajar dilakukan untuk menguji efektifitas dari fitur e-learning berbasis Chamilo yang telah dikembangkan. Hasil uji coba lapangan terhadap 30 peserta didik kelas $\mathrm{X}$ Multimedia SMK Negeri 5 Palembang dilakukan pretest dan posttest. Peningkatan hasil belajar dapat 
dilihat dari rata-rata pretest peserta sebesar 43,33 menjadi 82,83 pada hasil posttest. Peningkatan tersebut menunjukkan adanya perubahan hasil belajar sebelum dan sesudah belajar menggunakan fitur e-learning berbasis Chamilo. Peningkatan hasil belajar setelah menggunakan fitur e-learning berbasis Chamilo terbukti efektif untuk meningkatkan hasil belajar peserta didik dengan nilai $\mathrm{N}$-gain 0,70 . Adapun kategori hasil belajar menurut Hake $(2002$, p. 2). dibagi menjadi tiga yaitu jika $\mathrm{N}$-gain $>0,7$ termasuk kategori tinggi; jika $0,3 \leq N$-gain $\leq 0,7$ termasuk kategori sedang; jika $N$-gain $<0,3$ termasuk kategori rendah, maka dapat disimpulkan bahwa hasil $\mathrm{N}$-gain dari penelitian pengembangan fitur e-learning berbasis Chamilo berada dalam kategori tinggi.

Fitur e-learning yang telah berhasil dikembangkan ini relevan dengan penelitian Pande, Wadhai, dan Thakare (2016, p. 274) bahwa fitur e-learning dalam pendidikan sangat fleksibel dengan waktu dan tempat. E-learning juga dapat meningkatkan efesiensi pengetahuan dan kualifikasi melalui kemudahan akses informasi. Pande, Wadhai, dan Thakare (2016, p. 275) juga mengemukakan e-learning dapat memberi peluang untuk hubungan antara peserta didik dalam forum diskusi. Selain itu, e-learning memudahkan siswa memahami materi pembelajaran karena sudah disusun secara terstruktur dalam satu sistem e-learning. Teknologi e-learning harus diseimbangkan dengan kebutuhan peserta didik. Shen, Wang, dan Shen (2009, p. 176) mendeskripsikan sebuah e-learning yang efektif harus menggabungkan kebutuhan emosional peserta didik dengan platform e-learning. Shen, Wang, dan Shen (2009, p. 176) berhasil mengembangkan e-learning yang mencapai akurasi terbaik 86,3\% dalam implementasi pada pembelajaran. E-learning Shen, Wang, dan Shen (2009, p. 176) juga berhasil membantu meningkatkan pengalaman belajar peserta didik sesuai materi dan kebutuhan emosional siswa dengan peningkatan kinerja sebesar $91 \%$.

E-learning memiliki kecenderungan berpotensi menarik peserta didik ke dalam lingkungan belajar dengan manfaat yang melimpah. Devisakti dan Ramayah (2019, p. 86) melakukan sebuah penelitian yang menghasilkan 0,801 hingga 0,906 cronbach alpha yang berarti pengembangan elearning memiliki kehandalan yang baik. Devisakti dan Ramayah $(2019$, p. 86) menambahkan bahwa e-learning memiliki respon positif terbanyak dari pengguna lembaga bidang pendidikan. Fitur $e$ learning berbasis Chamilo relevan dengan penelitian yang dilakukan Yulita, Ambarwulan, dan Bakri (2018, p. 15). Penelitian Yulita, Ambarwulan, dan Bakri (2018) juga berhasil mengembangkan $e$ learning berbasis Chamilo. E-learning Yulita, Ambarwulan, dan Bakri (2018, p. 15) menggunakan metode pengembangan Research and Development (R\&D dan terbukti valid dengan perolehan persentase sebesar $86,67 \%$ dari ahli materi, 92,39\% dari ahli media, dan 94,47\% dari ahli pembelajaran. Selain itu, pengembangan e-learning oleh Yulita, Ambarwulan, dan Bakri (2018, p. 15) mendapatkan hasil uji kelayakan bahwa perangkat e-learning layak sebagai media pembelajaran yang dapat membantu menyampaikan materi dan tugas terstruktur siswa.

\section{SIMPULAN}

Berdasarkan hasil penelitian dan pembahasan mengenai pengembangan e-learning berbasis Chamilo pada pembelajaran simulasi dan komunikasi daring di SMK ditinjau dari proses pengembangan, menghasilkan fitur e-learning berbasis Chamilo telah teruji validitasnya setelah diuji melalui 3 aspek yaitu materi $(84,62 \%)$, media $(89,47 \%)$, dan desain pembelajaran $(81,82 \%)$. Berdasarkan ketiga kategori tersebut dapat diketahui bahwa multimedia interaktif ini valid dan layak untuk diujicobakan dengan revisi sesuai saran. Fitur e-learning berbasis Chamilo telah teruji kepraktisannya. Hal ini terlihat dari uji kepraktisan pada 3 orang peserta didik melalui pengisian angket didapatkan penilaian yang sangat praktis $(86,10 \%)$ pada setiap individu penilai, dengan mendapatkan penilaian yang sangat praktis, maka e-learning ini dapat digunakan untuk pembelajaran fitur kolaboratif daring.

Fitur e-learning berbasis Chamilo memiliki efektivitas terhadap peningkatan kompetensi peserta didik yang terlihat dari hasil belajar antara nilai pretest dan posttest. Pada pretest nilai didominasi pada kategori sangat kurang sedangkan pada posttest nilai didominasi pada kategori baik, hal ini dinilai sudah sangat efektif yang tergambar pada nilai $N$-gain yang masuk kategori tinggi yaitu 0,70. Efektifitas juga diukur berdasarkan ketuntasan hasil belajar dengan rata-rata 84,17. 


\section{DAFTAR PUSTAKA}

Alessi, S. M., \& Trollip, S. R. (2001). Multimedia for learning methods and development. Boston: Allyn and Bacon, Inc.

Devisakti, A., \& Ramayah, T. (2019). E-Learning usage outcomes among university learners: A Pilot Study. Journal of Education and e-Learning Research, 6(3), 149-155. Doi: https://doi.org/10.20448/journal.509.2019.63.149.155

Fadaei, A. S. (2019). Comparing two results: Hake gain and dellow gain, to analyze FCI data in active learning process. US-China Education Review, 9(1), 31-39. doi:https://doi.org/10.17265/2161-623X/2019.01.003

Hake, R. (2002). Relationship of individual student normalized learning sains in mechanics with gender, high-school physics, and pretest scorer on mathematics and spatial visualization. Physic Education Research Conference, 8(1), 1-14.

Pande, D., Wadhai, V. M., \& Thakare, V. M. (2016, February). E-learning system and higher education. International Journal of Computer Science and Mobile Computing, 5(2), 274280.

Shen, L., Wang, M., \& Shen, R. (2009). Affective e-learning: Using "emotional" data to improve learning in pervasive learning environment. Educational Technology \& Society, 12(2), 176189. doi:https://doi.org/10.2307/jeductechsoci.12.2.176

Somayeh, M., Dehghani, M., Mozaffari, F., Ghasemnegad, S. M., Hakimi, H., \& Samaneh, B. (2016). The effectiveness of e-learning in learning: A review of the literature. International Journal of Medical Research \& Health Sciences, 5(2), 86-91.

Sugiyono, S. (2016). Metode penelitian pendidikan: Pendekatan kualitatif, kuantitatif dan R\&D. Bandung: Alfabeta.

Wu, C., Chen, Y, \& Chen, T. (2017, October 26). An adaptive e-learning system for enhancing learning performance: Based on dynamic scaffolding theory. Eurasia Journal of Mathematics, Science and Technology Education, 14(3), 903-913. doi: https://doi.org/10.12973/ejmste/81061

Yulita, A., Ambarwulan, D, \& Bakri, F. (2018). Pengembangan e-Learning menggunakan Chamilo untuk membantu proses pembelajaran fisika SMA Kelas X Semester II. Gravity: Jurnal Ilmiah Penelitian dan Pembelajaran Fisika, 4(2), 15-25. doi:https://doi.org/10.30870/gravity.v4i2.4029 